\title{
The Effect of Pedagogic Competences toward Students' Satisfaction
}

\author{
Lelya Hilda \\ The Faculty of Tarbiyah IAIN Padangsidimpuan
}

\begin{abstract}
Nowadays, education must be able to compete with globalization. One of the importance factors is pedagogical competences that every student needs to have it to improve interesting and attractive as well as successful learning process. Based on the research result toward 200 students of Tarbiyah Faculty of IAIN Padangsidimpuan, it was found that students' satisfaction is categorized as good in the mean of 76.75 and 77.53 . The correlation 0.612 showed that there is a correlation and pedagocical competences affect only $37.4 \%$. Then, the hypothesis proved that there is a significant effect of pedagogical competences toward students' satisfaction with the result of anova $\mathrm{Fh}>\mathrm{Ft}=118.367>3.89$, sig $0.000<$ 0.05 , and the regression equation $\bar{Y}=0.561 \mathrm{x}+34.456$.
\end{abstract}

Key words: competences, pedagogic, satisfaction, education, learning.

\section{Introduction}

Development in the globalization era is a challenge for college in preparing its graduation to be able to compete in working field and producing creative and innovative graduation. Internationally, Asean Free Trade Area (AFTA) and Asean Free Labour Area (AFLA) started in 2003 while Masyarakat Ekonomi Asean (MEA) has just started in 2015. It means that competition in working field will open; consequently the local workers must be able to compete with foreign workers from other countries. Indonesian workers will be hit by Malaysian, Philipinian, Bangladesh, and Indian if they can't compete with them (Athanasia, dkk., 2014).

Efforts to fulfill students' needs are keys to win this competition. Agreement between needs or customer voice and company voice demand is an important condition and key to create success in college instructional process (Prasetyaningrum, 2009: xiv).

Today education must create students to be able to face globalization era, environment problem, information technology growing, knowledge and technology converse, knowledge based economy, development of creative industry and culture, changes in economy power, and causes and effects in science based technology. To face challenges in Masyarakat Ekonomi Asia (MEA), education function is needed to create students who have oriented knowledge and technology (IPTEK) and good believe as well as religious (IMTAK) and have ability in many aspects i.e. the teachers who can give inspirations to students to think innovatively and have competitive spirit in many live aspects in order to face globalization era (L. Hilda, 2017).

University as one of higher education provider must have high functions in developing this nation. There are two main tasks that the universities have, they are educating students to have IPTEKS and developing nations including preparing the candidates for nations leaders who have good characters and cultures. University also has function to produce human resources for society, and to increase, spread, and develop IPTEKS itself.

Globalization can be seen from lots of information and there is no limit between countries as effects of communication technology development. Then, all information must be responded well and wisely. So, the existence of university is still needed.

Universities must do much anticipation to face competitive challenges and must take responsibility to create and develop all service aspects that they have, because university service can describe their quality. If the consumers' service that is given is good, the quality of the university can be regarded as good. 
However, if the service is regarded as bad, the quality is also said to be bad. This is also including service in all aspects of university. The research related to problems that faced by university in measuring service quality, its accreditation scoring and its degree of students' failure is regarded to be lack and there is a need to have new paradigm as indicators in measuring education quality(M. Sadat, 2000:1).

Lots of society demand toward formal higher education specifically university has forced the university as strategic sector to produce qualified human resources. Then, university as service industry must think deeply about the importance of service to consumers, because it is known that consumers' satisfaction is seen to be vital aspect in surviving in business competition (F. Tjiptono, 2004:145).

Education is the main point of nation development to create qualified life of society. In this case, government must try to prioritize the development in edication sector by increasing education quality to produce qualified as well as productive human resources. Education department has main function to provide graduation that is not only enormous but also qualified and high discipline. Also education must be able to become denominator, innovator, motivator, and developer, as well as producer of workers that are qualified in many aspects and skills. Therefore, society service including students' service must be increased whether from quality or quantity aspect.

The faculty success as one of department in university is determined by its service quality that is given to students, in this case, qualified service can be indentified through consumers satisfaction (students). Srinida and Nilakusuma say that "to achieve higher satisfaction, understanding about what consumers demand is needed, by increasing each person commitment to provide consumers' demand (M. Srinadi dan E. Nilakusmawati, 2008).

There are some aspects that must be understood by university as knowledge providers, i.e. the more numbers of students, the more difficult to know the consumers well, specifically about the opinion whether they like the service given or not, and also about their reasons on it.

Competence is a set of knowledge, skills, and behavior that the teachers must have in running their profession. To be able to run teaching process well, the lecturers must have professional competence, pedagogical competences, social and personality competences. The lecturers are professional educators and someone who have knowledge to transfer, develop, and spread the knowledge, technolopgy, and arts through education, research, and working with society.

In government rule no. 142005 about teachers, lecturers, it is stated that pedagogic competence is "ability to manage teaching and learning for students and learners". The department of education says that this competence as learning management skills. This competence can be seen from teachers' ability in planning the lesson and learning, ability in doing interactions and running the instructional process well, and ability in evaluating the learning process (Direktorat Tenaga Kependidikan Depdiknas, 2004:9).

Pedagogic competence is really needed in learning process. In learning process, a teacher or lecturer must master her or his task as someone who is professional in educating students, treating and training. Educating means continuing and increasing life value, developing knowledge and technology, while training means developing skills for students.

In addition, conducive teaching and learning must be created because there are tendencies among lecturers who only teach by transferring knowledge and skills without giving guidance to students. Guiding students can be seen as the ways to show the students about their life principle, also about the ways how to achieve their dream, then also about how to learn and study effectively and diligently.

There have lots of issues about quality of higher education or university nowadays. However, the issues or comment are only said as spoken issues which are not really taken into account, because the students can only feel but cannot prove their comment. This is because there is no data that can be used to prove and show what and how their problems are. Therefore, there is a need to find where the weaknesses are related to service.

The students' comment related to the service weaknesses and its quality given by university in this case must be respected and taken into account. Therefore, there must be empirical proves about the truth of issues that are directed to university service. To know the effect of pedagogic competence toward students' satisfaction, there is a need to find the ways personally or holistically.

Through the variety of competition and lots of comment among society toward education stakeholders, Tarbiyah Faculty of IAIN must prepare themselves to increase teaching and learning process and develop their service quality to get students' satisfaction. According to Phillip Kotler in Supratna, it is 
said that service is satisfying if what is felt is similar or more than what is hoped. This kind of service is perceived as qualified and ideal service (J. Supranto, 2006: 231).

Students' satisfaction must be respected so learning process can run well and it is one thing that university must pay attention toward it. Pedagogic competence is one of the competences that the teachers or lecturers must pay its attentions this is to create conducive and interesting learning condition.

By developing pedagogic competences, students' learning satisfaction can be increased. Therefore, the researcher is interested in doing research about the effect of pedagogic competences toward students' satisfaction. This research is done in Tarbiyah Faculty of IAIN Padangsidimpuan.

\section{Research Design}

a. Kind of Research

This research was a type of quantitative research that focused on numerical data that was analyzed using statistical method. According to Subana and Sudrajat, quantitative research is seen from its purpose, this research is used to test the hypothesis and theory, to prove the fact and describe the statistic, and to show the relation between variables, also to develop concept and to develop understanding as well as to describe things (Subana dan Sudrajat, 2005: 25).

This research was a correlation based research. This correlation research analyzed correlation between two variables, not only in form of cause and effect but also effects between two variables (Subana dan Sudrajat, 2005: 26).

\section{b. Population and Sample}

Sugiyono says that "population is generalization area that consists of object and subject that has certain quality and characteristics decided by the researchers to be analyzed and be concluded (Sugiyono, 2009, 97): Then, Arikunto also says that "population is all objects that are analyzed in research" S. Arikunto, 2009:130).

In this research, there were 2186 students of Tarbiyah Faculty who were still active and they were in semester II until XIII. However, the students who became objects in this research were only students from semester IV until semester VIII that consisted of 1350 students.

Andi Bulaeng says that sample is parts of population that practically consist of small unit of sample that is proportional and they are target elements that are chosen. Sample must be representative and can represent population that becomes research samples to achieve valid result and accurate data. In choosing samples, this research used random sampling because in choosing the samples, the researcher mix all subjects so that all subjects are regarded similar to be chosen (Andi Bulaeng, 2004, 134). According to Suharsimi Arikunto, if the number of population is more than 100, number of sample that is chosen is minimally 10-25\% (Arikunto, 2009, 13). Therefore, number of Tarbiyah Faculty students that was chosen as population was 1350 students and number of sample was $15 \%$ from 1335 i.e. 200 students.

\section{c. $\quad$ Research Framework}

To see the functional relation between variables, survey method of correlation was used. This survey used quantitative approach and analyzed the data using double linier regression. The researcher took one of more than one free variable (predictor) and tested the data by finding its functional relation toward responded variable ( as dependent variable).

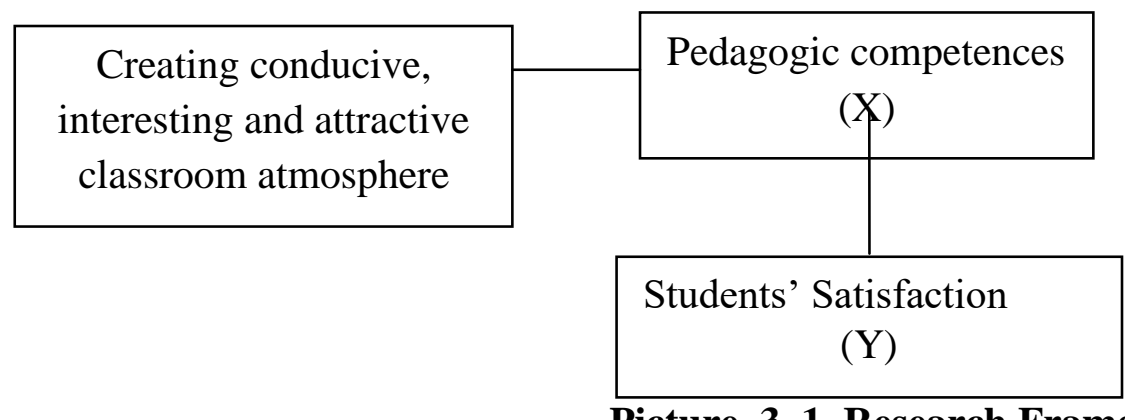

Notes:

Picture. 3. 1. Research Framework

$\mathrm{X} \quad$ : Pedagogic competences

Y : Students' Satisfaction 


\section{d. Data Collection Technique}

Data collection technique that was used in this research was survey technique. Survey is sets of questions that are systematically written and filled in by the respondent. Then, after the survey was answered, it was returned and given back to the researcher (B. Bungin, 2005, 123).

The types of questions that were given were closed questions which mean that they were arranged well to record the data related to respondents' condition. All the alternative answers that would be answered had been given in the survey. Then, the respondents had to choose one of the answers that they thought correct and the respondents could not give and write their own answers in the survey.

\section{Finding and Discussion \\ Finding}

\begin{tabular}{|l|r|r|r|}
\hline \multicolumn{3}{|c|}{ Statistic Description } \\
\hline & Mean & $\begin{array}{c}\text { Std. } \\
\text { Deviation }\end{array}$ & \multicolumn{1}{c|}{$\mathrm{N}$} \\
\hline $\mathrm{Y}$ & 77.53 & 10.79219 & 200 \\
$\mathrm{X}$ & 76.75 & 11.76220 & 200 \\
\hline
\end{tabular}

The mean that is derived from lecturers' competence $(\mathrm{x})$ is 76.75 and students' satisfaction (y) is 77.53 which is categorized as good. Then, each deviation standard is 11.76 and 10.79 .

\begin{tabular}{l|c|r|r|r|}
\hline Model & \multicolumn{1}{|c|}{ Model Summary } \\
\hline 1 & $.612^{\mathrm{a}}$ & .374 & \multicolumn{1}{c|}{$\begin{array}{c}\text { Adjusted R } \\
\text { Square }\end{array}$} & $\begin{array}{r}\text { Std. Error of } \\
\text { the Estimate }\end{array}$ \\
\hline
\end{tabular}
a. Predictors: (Constant), X
b. Dependent Variable: Y

From the table above, it is derived that there is a big correlation between pedagogic competence and students' satisfaction with the value 0.612 which is categorized as strong. Meanwhile, the number of effect of pedagogic competence toward students' satisfaction is $37.2 \%$ and another $62.8 \%$ is affected and influenced by other factors.

ANOVA ${ }^{b}$

\begin{tabular}{|c|c|c|c|c|c|c|}
\hline \multicolumn{2}{|c|}{ Model } & $\begin{array}{l}\text { Sum of } \\
\text { Squares }\end{array}$ & df & Mean Square & $\mathrm{F}$ & Sig. \\
\hline \multirow[t]{3}{*}{1} & Regression & 8671.843 & 1 & 8671.843 & 118.367 & $.000^{\circ}$ \\
\hline & Residual & 14505.977 & 198 & 73.263 & & \\
\hline & Total & 23177.820 & 199 & & & \\
\hline
\end{tabular}

a. Predictors: (Constant), X

b. Dependent Variable: Y

From the Anova table above, it is shown that lecturer's pedagogic competences affect students' satisfaction significantly with the sig value $.00<0.05$ with the $\mathrm{F}$ value $>\mathrm{F}$ table $(\alpha 0.05) 118.367>3.89$

\section{Coefficients}

\begin{tabular}{|c|c|c|c|c|c|c|}
\hline \multirow{2}{*}{\multicolumn{2}{|c|}{ Model }} & \multicolumn{2}{|c|}{$\begin{array}{c}\text { Unstandardized } \\
\text { Coefficients }\end{array}$} & \multirow{2}{*}{$\begin{array}{c}\begin{array}{c}\text { Standardized } \\
\text { Coefficients }\end{array} \\
\text { Beta }\end{array}$} & \multirow[b]{2}{*}{$\mathrm{t}$} & \multirow[b]{2}{*}{ Sig. } \\
\hline & & B & Std. Error & & & \\
\hline \multirow[t]{2}{*}{1} & (Constant) & 34.456 & 4.005 & & 8.603 & .000 \\
\hline & $X$ & .561 & .052 & .612 & 10.880 & .000 \\
\hline
\end{tabular}




\section{Coefficients}

\begin{tabular}{|c|c|c|c|c|c|c|}
\hline \multirow{2}{*}{\multicolumn{2}{|c|}{ Model }} & \multicolumn{2}{|c|}{$\begin{array}{l}\text { Unstandardized } \\
\text { Coefficients }\end{array}$} & $\begin{array}{c}\text { Standardized } \\
\text { Coefficients }\end{array}$ & \multirow[b]{2}{*}{$\mathrm{t}$} & \multirow[b]{2}{*}{ Sig. } \\
\hline & & B & Std. Error & Beta & & \\
\hline 1 & (Constant) & 34.456 & 4.005 & & 8.603 & .000 \\
\hline & $X$ & .561 & .052 & .612 & 10.880 & .000 \\
\hline
\end{tabular}

a. Dependent Variable: $Y$

Regression equation $\mathrm{Y}=0.561 \mathrm{x}+34.456$

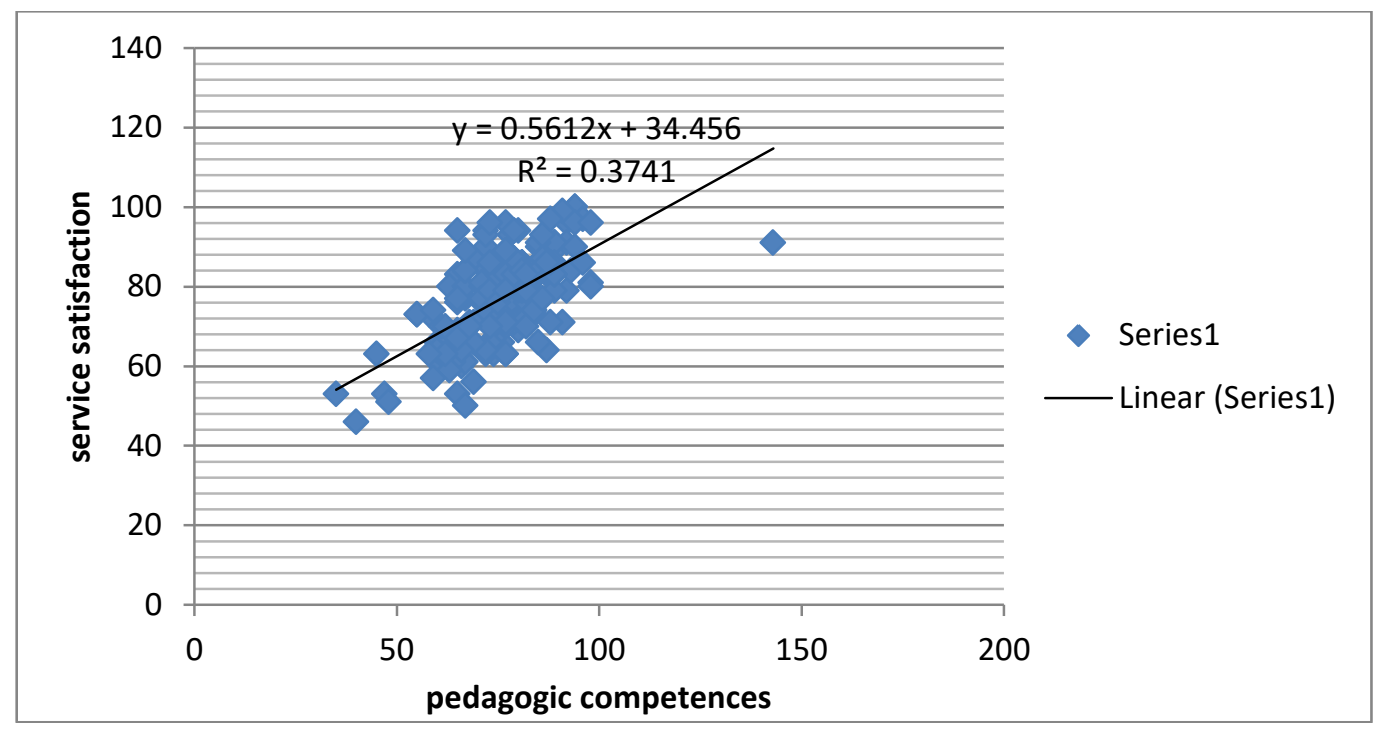

\section{Discussion}

Students' satisfaction in education and learning process must be perceived to be serious in order to increase learning process and students' satisfaction, so the quality and quantity of students can be increased. The result of statistic description shows that the mean of pedagogic competence is 76.75 and the service quality is 77.53 which is categorized as good.

Mulyasa $(2011,79)$ says that "pedagogic competence is very important because it determines the learning process success that directly touches learning ability that involves students' management, learning planning, teaching framework, learning evaluation and development of students' potentials. Those potentials include (1) mastering students' characters, (2) mastering learning theory, (3) developing curriculum, (4) running the teaching (5) making use of information technology, (6) developing students' potentials, (7) communicating well, (8) making use the learning evalution for learning aims, (10) doing reflections".

Pedagogic competence must be built so that teachers' activity (planning, posing questions, deciding tasks, and predicting) can be done to increase students' creativity (A. L. Mirzagitov \& L. G. Akhmetov , 2015, 114-121).

Pedagogic competences involve understanding students, designing instructional process, doing educative and diagnostic learning, evaluating learning, and developing students to actualize their potentials. Students' interest in learning is determined by the teachers' good characters. This character is really needed by students and learners (A. Hakim, 2015, 2319 - 1805.)

From the hypothesis testing, it is proved that there is an effect of pedagogic competence toward students' satisfaction with the Anova value F $=118.367>3.89$, sig $0.000<0.05$, correlation 0.612 (strong), and it only affects $37.4 \%$. The regression linier $\bar{Y}=0.561 \mathrm{x}+34.456$ shows that every one sector $\mathrm{X}$ (pedagogic competence) rises, so Y (students' satisfaction) rises into 34.456, it means that there is a positive relation saying that if the $\mathrm{X}$ rises, the $\mathrm{Y}$ will also rise.

From the research conducted by C. S. Long, Z. Ibrahim \& T. O.Kowang (2014, 37-46), it is shown that lecturers' knowledge about the subjects contributes to students' satisfaction. Meanwhile, Adnan Hakim's research shows that the data analysis result using double regression describes that partially 
pedagogic competence, personal competence, professional competence, and social competence have significant effect in increasing learning performance. The contributions of all these competences are said to have effects in increasing work quality in teaching and learning process (A. Hakim, 2015, 1).

\section{Conclusion}

From the research result and finding, it can be concluded that the mean of pedagogic competence is 76.75 and service quality is 77.53 which is categorized as good. From the hypothesis testing, it can be seen that there is a significant effect of pedagogic competence toward students' satisfactions with the value of Anova test $\mathrm{F}=118.367>3.89$, sig $0.000<0.05$, the correlation is strong, and it only affects $37.4 \%$. From the regression linier $\bar{Y}=0.561 \mathrm{x}+34.456$, it is shown that every $\mathrm{X}$ (pedagogic competence) rises, so $\mathrm{Y}$ (students' satisfaction) also rises, it means that there is a positive relation between them saying that if the $\mathrm{X}$ rises, the $\mathrm{Y}$ will rise and vice verse.

\section{References}

[1] Arikunto, S. (2009). Prosedur Penelitian Suatu Pendekatan Praktek. Jakarta: Rineka Cipta.

[2] Athanasia Budi Astuti, dkk.. (2014). "Pengaruh Kualitas Pelayanan Akademik Terhadap Kepuasan Mahasiswa di Jurusan Terapi Wicara Poltekkes Kemenkes Surakarta", Jurnal Terpadu Ilmu Kesehatan, Volume 3, No 2, November 2014, 106-214.

[3] Bulaeng, A. (2004). Metode Penelitian Komunikasi Komputer, Yogyakarta: PT.Andi Offset.

[4] Bungin, B. (2005). Metodologi Penelitian Kuantitatif Edisi Pertama. Jakarta: Prenada Media.

[5] Hakim, A. (2015). Contribution of Competence Teacher (Pedagogical, Personality, Professional Competence and Social) On the Performance of Learning, The International Journal Of Engineering And Science (IJES), Volume 4 (2), 2319 - 1805.

[6] Indah Dwi Prasetyaningrum. (2009). Analisisis Pengaruh Pembelajaran dan Kualitas Pelayanan Terhadap Kepuasan Mahasiswa dan Loyalitas Mahasiswa (Studi Kasus Pada Undaris Ungaran). Tesis, PPS Universitas Diponegoro Semarang.

[7] Lelya Hilda. (2017). Pembelajaran Berbasis Saintifik dan Multikultural Dalam Menghadapi Era Masyarakat Ekonomi Asean (MEA), conference.kuis.edu.my/pasak2017.

[8] Long, C. S., Ibrahim, Z. \& Kowang, T. O. (2014). An Analysis on the Relationship between Lecturers' Competencies and Students' Satisfaction, International Education Studies; Vol. 7 (1), .3746.

[9] Mulyasa, E. 2011. Standar Kompetensi dan Sertifikasi Guru. Bandung :Remaja Rosdakarya.

[10] Mirzagitova, A. L. and Akhmetov, L.G. (2015). " Self-Development of Pedagogical Competence of Future Teacher, International Education Studies"; Vol. 8 (3), 114-121.

[11] Sadat, M. (2000). “Analisis Hubungan Kinerja Jasa Perguruan Tinggi terhadap Kepuasan Mahasiswa: Studi Kasus Universitas Indonesia. Tesis,: Pascasarjana Universitas Indonesia.

[12] Srinadi, I. G.A. M. dan Nilakusmawati,D.P.E. (2008). "Faktor-Faktor Penentu Kepuasan Terhadap Pelayanan Fakultas Sebagai Lembag Pendidikan (Studi kasus di FMIPA, Universitas Udayana) “,Cakrawala Pendidikan, November 2008, Th. XXVII, No. 3,.217-231.

[13] Subana dan Sudrajat. (2005). Dasar-Dasar Penelitian Ilmiah. Bandung: CV Pustaka Setia.

[14] Sugiyono. (2009). Metode Penelitian Kuantitatif, Bandung: Alfabeta. 
[15] Supranto, J. (2006). Pengukuran Tingkat Kepuasan Pelanggan, Jakarta: PT. Rineka Cipta.

[16] Tjiptono, F. (2004). Manajemen Jasa. Yogyakarta: Andi Offset. 